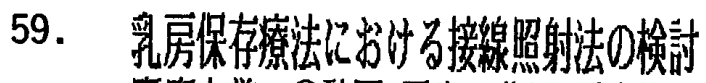

鹿応大学 O砂岡 正良 北川五十雄 五味 直人

金沢大学医学部附属病院 村田 秀雄松本進 倉田 雄一

我々の施設ではここ数年、罗癌に対して保存療法を行っている。その照射法の具体的な技術に関しては88年の縔 会において報告したが、接線照射をする際には肺の一部が照射され、Radiation Pneumonitis 等の障害をおこす要因 とむなりうる。また腺組織はその形熊等、個人差が大きく、症例によっては大きく肺が照射されることすある。シ ミュレーションをする際には照射する肺の幅が5 c mを超えた場合に照射野の再検討を行っているが、照射野と乳腺

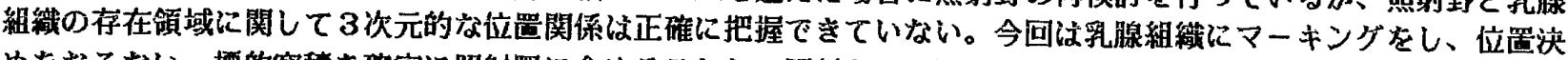
めを扢こない、標的容積を確実に照射野に含めることと、照射される肺の容䄼を少なくするための照射野下端の位圆 を検討した。乳腺組維の比較的大きい症例では照射する肺の幅が $5 \mathrm{~cm}$ 超えないと販腺組織を充分照射できない場 合むあった。

60. ラルスを用いた胆管内腔内照射法

千葉県がんセンター ○岩瀬勉 石垣秀世 宇田川王男 山口京子 斉藤正美

（目的）腔内照射法は体外照射に比して副作用が少なく局所に大線量の放射線を照射する事ができるので強い抗腫曒 効果が期待できる、そこでラルスを用いた胆管内腔内照射法を行なうためのアプリケータを試作しそれを臨床に応用 したので報告する。

(方法)すでに胆管内に留置してあるP T C S チューブへガイドワイヤーを通して胆管に誘導し P T C S チューブを 抜去する、残つたガイドワイヤーにアプリケータを通して胆管内へ挿入する、治療範囲の確定を行なうためにアプリ ケータを通して造影䯇を注入し胆管造影を行ないその後ラルスに接続して治療を行なう。

(結果) 照射時間が短い・術者の被爆が少ない・照射線量、線量分布を操作しやすい等のラルスの特徵をいかした胆 管の腔内照射が可能になり良好な局所コントロールが得られた。

61. I.I 像によるRALS 治療計画の試み

癌研究会附属病院○桑原秋夫 長堀孝史 高橋民雄 吉阙実和久井聖 東芝メデカル 広瀬一男

（目的）R A L S の治療計画に視野可変型 I . I を利用し、線源位置の取得ならびに、前回線源配置との比較をモニタ 画面上ですみやかに行ない、絽返しの再現性を高める。

(方法) 4.5インテの I.I 透視像を画像メモりに取りこみ、デジタイザーにてカーソルを移動し、モニタ上にて模擬 線源の位置を取得する。計算結果はオンラインで治療装置に送り即特性を得る。2回目以後の治療に際しては、 前回の線源配置をモニタ上で外子宮口を合わせて重ね、比較を行なったのち位置入力にうつる。

(結果) 線源配罗, 取得精度は拡大像であるため、補正なしでも辺緑部で数 $\mathrm{m} \mathrm{m}$ 程度で、リンクサイズの入力ではフ イルムより有利である。また、前回線源配置をモニタ画面上で、外子宮口を合わせて重ねるので、容易に前回と の比較ができ、配置の修正に役立つ。

\title{
62. 巨大ツーブスを用いた電子線全身照射法
}

\section{久留米大学病院 ○才田舟文 中䲴法忠 井口安則 河村政秀 中野英雄}

[目的］急性白血病の全身皮局転移放射線治療として，電子線全身照射法がおこなわれている。この照射法にお いて、電子線の平坦度、線量分布を均一にするためにいろいろな方法が用いられているが、今回我々は90×9 ○的の巨大ツーブスを使用することにより、安定した平坦度、及び均等な線量分布が得られたので報告する。

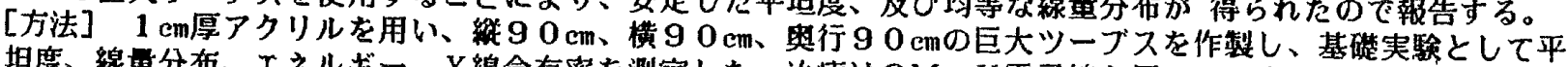

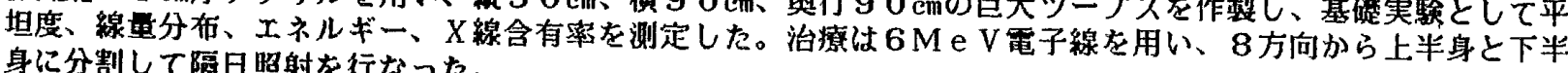
身に分割して隔日照射を行なった。

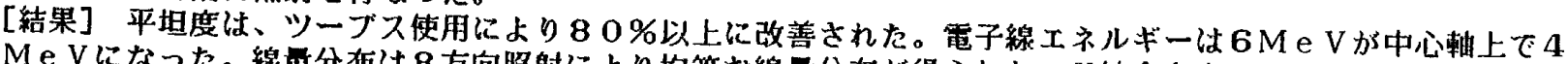

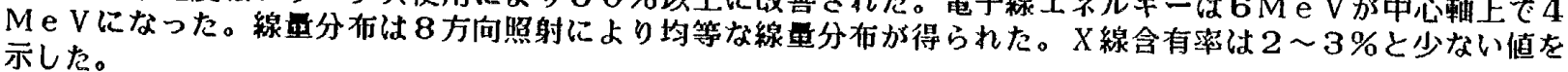

